\title{
Metal debris concentrations in soft tissues adjacent to loosened femoral stems is higher in uncemented than cemented implants
}

\author{
Krzysztof Kmieć, Marek Synder, Piotr Kozłowski, Marek Drobniewski and Marcin Sibiński ${ }^{*}$
}

\begin{abstract}
Background: There are still many questions related to aseptic femoral stem loosening. Systemic and local immune responses to the implanted "foreign body" is one of the reasons for loosening. The purpose of the study was to measure metal ion concentration ( $\mathrm{Ti}, \mathrm{Co}, \mathrm{Cr}, \mathrm{Mo}, \mathrm{Ni}, \mathrm{Al}$ ) around loosened femoral stems and compare their levels around uncemented and cemented implants.

Methods: This paper reports 50 hips operated for isolated stem loosening, in 50 patients at the mean age of 57 years (from 21 to 87). There were 25 cemented (Co, $\left.\mathrm{Cr}_{29}, \mathrm{Mo}, \mathrm{Ni}\right)$ and 25 uncemented (Ti, Al) stems. The mean follow-up from primary hip replacement to revision was 10.1 years (from 0.5 to 17). During the procedure, scar tissue around the stem was taken for analysis of metal ions.

Results: The concentrations of titanium and aluminium in soft tissues around uncemented loosened stems were higher than cemented ones ( $p<0.001, p<0.001$ respectively). However, no statistically significant differences were observed between both types of stems in terms of ions of the metal of which cemented implants had been made of $(\mathrm{Co}, \mathrm{Cr}, \mathrm{Mo}, \mathrm{Ni})$.

Conclusions: In soft tissue around a loosened stem, the concentrations of metal ions from implants are much higher in case of uncemented stems than of cemented ones. Metal ions from vitalium femoral heads were found around uncemented stems in similar values to cemented streams.
\end{abstract}

Keywords: Metal debris, Stem loosening, Hip revision, Cemented implants, Uncemented implants

\section{Background}

There are still many questions related to aseptic femoral stem loosening which, as a clinical problem, remains till now unresolved. On the other hand, this lack of clear and simple explanation of the mechanisms, which are behind the stem loosening process. There is a complexity of different factors, resulting from the anatomical structures, external to the femoral stem, biased by patient's body biomechanisms, influenced the way the stem has been implanted, as well as affected by the systemic and local immune responses to the implanted "foreign body" [1-3]. It should also be noted that the materials, which the implants are produced of (metals, polyethylene, ceramics) significantly differ in their physicochemical characteristics

\footnotetext{
*Correspondence: sibinek@poczta.onet.pl

Clinic of Orthopaedics and Paediatric Orthopaedics, Medical University of Łódź Poland, Drewnowska 75, 91-002 Lodz, Poland
}

from the properties of live tissues, if not infrequently inducing mutual reactions [4]. First of all, the implants are submitted to physical laws of irreversible wear and products of this wear deposit in tissues, where they may trigger various harmful and, by all means, adverse effects $[5,6]$.

Revisions of hip arthroplasties revealed particles of metal wear, both on the surface of removed implants and in surrounding tissues. The aim of the study was to measure metal ion concentration (titanium - $\mathrm{Ti}$, cobalt - Co, chrome - Cr, molybdenum - Mo, nickel - Ni, aluminium $\mathrm{Al}$ ) around loosened femoral stems and compare their levels around uncemented and cemented implants.

\section{Methods}

During the years 2007 and 2009, a total of 172 patients were submitted to revision hip arthroplasty, performed at our Department for aseptic cup and/or stem loosening. 
Out of them, 50 hips were operated for isolated stem loosening, 99 for isolated cup loosening and 23 for loosening of both components. Only homogenous group of patients were included in the study. To eliminate influence of cup loosening on irons metal level, we limited our study to hips with isolated stem loosening. This paper reports 50 hips, operated in 50 patients for aseptic, isolated femoral stem loosening, one of them having, additionally, stem fracture. There were 35 women and 15 men in the group at the mean age of 57 years (the age range from 21 to 87 years). The left hip was operated in 24 and the right one in 26 cases. The indications for primary hip replacement included idiopathic coxarthrosis in 27 hips, femoral fracture in 11, dysplastic coxarthrosis in 9 and aseptic necrosis of femoral head in 3. Different types of hip replacement were performed in the study group. Half of them had cemented implants (Weller's (Aesculap) in 15, Exeter (Howmedica) in 5, Centrament (Aesculap) in 5 patients), while the other half uncemented stem implants (Mittelmeier (Osteo) in 9, Parhofer - Mönch (Aesculap) in 8 , Bicontact (Aesculap) in 8 patients). The cemented stems were made of vitalium (Co, $\mathrm{Cr}_{29}, \mathrm{Mo}, \mathrm{Ni}$ ) and the uncemented ones of titanium, aluminium and vanadium alloys. In all patients, vitalium heads were used. All the cemented cups were made of polyethylene. The uncemented cups were made of titanium alloy with a polyethylene insert. No hybrid arthroplasties were performed in the group. The mean follow-up from primary hip replacement to revision was 10.1 years (the range from 6 months to 17 years). There was no statistical differences between cemented and uncemented stem group in terms of: age (53 versus 60 years, respectively, $\mathrm{p}=0,2)$, gender $(\mathrm{p}=0,75)$, follow-up (9.8 versus 10.4 years respectively, $\mathrm{p}=0,5$ ) or indication for primary surgery $(\mathrm{p}=0,8)$.

It was a prospective study. The diagnosis of implant loosening was obtained on the basis of clinical examination and radiographic evaluation and finally confirmed during revision hip arthroplasty. Stem loosening was diagnosed on the basis of radiographic criteria proposed by Gruen et al. [7]. Diagnosis of cup loosening was set with the use of DeLee and Gruen classification system [8].

Revision hip arthroplasty was performed in supine position from the anterolateral approach between the gluteus medius and the vastus lateralis muscle or, in case of extensive soft tissue scaring, the transgluteal approach was applied. Scar tissue and ectopic bone were removed. During the procedure, scar tissue around the stem was taken for analysis of metal ions.

Soft tissue samples, collected during revision operation, were analyzed for ions of the metals from the stems had been ( $\mathrm{Ti}, \mathrm{Co}, \mathrm{Cr}, \mathrm{Mo}, \mathrm{Ni}$ and $\mathrm{Al}$ ). The measurements were performed by ICP - MS (Inductively Coupled Plasma Mass Spectrometry). Calibration of the spectrometer was done, using the ICP multi - element standard solution VI by Merc. Before analysis, the probes were processed by microwave energy in solution of an MLS 1200 system by Milestone and of properly concentrated and spectrally clear nitric acid $\left(\mathrm{HNO}_{3}\right)$. The quality of obtained results was verified by control samples.

The research project was approved by the Bioethics Commission at our institution (Protocol No. RNN/2/12/ $\mathrm{KE})$. Written informed consent for participation in the study was obtained from participants.

Statistical analysis. The obtained results were submitted to a statistical analysis by the STATISTICA 10.0 PL software. Before an analysis of measurable features was undertaken, the compatibility of their distributions with the normal distribution was evaluated. The $\lambda$ - Kolmogorov test of goodness of fit with normal distribution was applied. Since the distributions of the analysed features significantly differed from the normal distribution, the Mann-Whitney test was applied for a comparison of medians. For comparison of demographic data between cemented and uncemented group was done using $\mathrm{chi}^{2}$ test, ANOVA and Student T test. Values $\mathrm{p}<0.05$ were regarded statistically significant.

\section{Results}

The concentrations of titanium in soft tissues around uncemented loosened stems were about hundred times higher than in soft tissues around cemented ones. The concentration of aluminium was about thirteen times higher in case of uncemented stems than of cemented ones. Both differences were statistically significant. However, no statistically significant differences were observed between both types of stems in terms of ions of the metal of which cemented implants had been made of (Co, Cr, Mo, Ni) (see Table 1).

\section{Discussion}

Despite the continued process of improving femoral stem structures and technologies, as well as more and more effective surgical techniques, aseptic loosening of implanted femoral stems has remained one of the major problems of femoral joint arthroplasty. It is generally known that, in in vivo conditions, metal implants release ions to surrounding tissues, which ions permeate then with blood to internal organs of operated patient. High concentrations of ions result in numerous. physiologically adverse effects, including cytotoxicity, genotoxicity, carcinogenicity and increased sensitivity (allergy) to metals $[3,9,10]$.

Available reports provide examples of increased concentrations of cobalt, chromium, nickel, titanium, molybdenum, aluminium and vanadium ions in implant surrounding tissues $[11,12]$. It has also been proven that ions of these metals affect bone metabolism, compromise the immune system, trigger late type allergy 
Table 1 Metal ion concentrations in cemented and uncemented stems, together with statistical comparison

\begin{tabular}{|c|c|c|c|c|c|c|c|c|}
\hline \multirow[t]{2}{*}{ Metal ions } & \multirow{2}{*}{$\begin{array}{l}\text { Type of stem } \\
\text { fixation }\end{array}$} & \multicolumn{6}{|c|}{ Parameters of ion concentration in $\mu \mathrm{g} / \mathrm{kg}$} & \multirow[t]{2}{*}{$P$ and $Z$ value } \\
\hline & & $\min$ & $\max$ & $\mathrm{x}$ & $\mathrm{Me}$ & SD & v (\%) & \\
\hline \multirow[t]{2}{*}{ Titanium } & Cemented & 118.6 & 1196 & 516.7 & 423.4 & 303.2 & 58.7 & $z=5.937 ; p<0.001$ \\
\hline & Uncemented & 768.5 & 999999 & 55308.6 & 12268.6 & 197431.8 & 356.9 & \\
\hline \multirow[t]{2}{*}{ Aluminium } & Cemented & 103.5 & 1234.5 & 278.8 & 154.7 & 270.7 & 97.1 & $z=5.879 ; p<0.001$ \\
\hline & Uncemented & 567.8 & 7977.2 & 3779.8 & 3464.7 & 2374.0 & 62.8 & \\
\hline \multirow[t]{2}{*}{ Nickel } & Cemented & 38.8 & 204230.4 & 8580.5 & 365.5 & 40765.5 & 475.1 & $z=1.572 ; p>0.05$ \\
\hline & Uncemented & 54.4 & 1353.7 & 568.3 & 468.2 & 438.5 & 77.2 & \\
\hline \multirow[t]{2}{*}{ Chrome } & Cemented & 88.6 & 1494.6 & 532.3 & 347.5 & 451.6 & 84.8 & $z=0.854 ; p>0.05$ \\
\hline & Uncemented & 113.4 & 1345.8 & 553.7 & 455.7 & 347.8 & 62.8 & \\
\hline \multirow[t]{2}{*}{ Cobalt } & Cemented & 2.5 & 327.6 & 85.9 & 23.3 & 108.6 & 126.5 & $z=1.717 ; p>0.05$ \\
\hline & Uncemented & 11.2 & 367.3 & 124.4 & 44.8 & 126.3 & 101.5 & \\
\hline \multirow[t]{2}{*}{ Molybdenum } & Cemented & 32.9 & 47855.3 & 2165.2 & 198.8 & 9522.7 & 439.8 & $z=1.455 ; p>0.05$ \\
\hline & Uncemented & 12.9 & 999999 & 40787.9 & 444.7 & 199841.3 & 489.9 & \\
\hline
\end{tabular}

Min - minimum, max - maximum, $x$ - mean, Me - median, SD - standard deviation , v (\%) - variance, $p$ - statistical significance ( $\mathrm{P}$ - value), $\mathrm{z}$ - $\mathrm{z}$ value. Bold fonts indicate significant differences.

and induce pathophysiology of aseptic implant loosening process in operated patients after femoral joint arthroplasty [10]. Additionally, the metal parts of implants undergo direct biocorrosion, caused by the activity of osteoclasts, what leads to release of large amounts of wear particles and metal ions to surrounding tissues [13-15]. Released metal ions reversely stimulate both the immune system and bone metabolism via a number of direct and indirect reactions, leading to an increased osteolytic activity in implant surrounding bone [16-19]. Wear particles may develop biological activity along different cellular pathways. They activate macrophages, foreign body giant cells, as well as fibroblasts of the periprosthetic membrane. These cells induce particledependent bone resorption by means of proinflammatory cytokines, such as IL-1beta, TNF-alpha, IL-6 and PGE2. These factors activate osteoclasts, as well as suppress osteoblasts [20].

This article reports ion concentration in a homogenous group of patients, that had isolated femoral stem loosening. In our study, ions of stem metals permeated from uncemeneted implants into surrounding tissues in concentrations higher than for cemented implants. Ions from metals of the evaluated cemented implants were found in tissues surrounding bone cement in concentrations insignificantly different from concentrations of those ions around uncemented stems. Interestingly, metal ions from vitalium were found around uncemented stems sometimes in values higher than in streams made of vitalium. This observation suggests that these metal debris comes from metal femoral heads and may be a result of electrolysis process between two types of metal.

Similar findings were reported by Hirakawa et al., who analyzed wear debris from failed total hip in 123 tissue samples. More particles were found adjacent to failed titanium-alloy stems and cups than to all-cobaltchromium-alloy prostheses. Higher concentrations of particles were found in fixations without cement, longer follow-up and in younger patients [21]. In Brien's report, levels of metal ions from femoral stems were evaluated in the synovial membrane and in the arthral fluid. The applied implants were made of stainless steel, a kobalt-chromium alloy and titanium alloys and fixed in bone with PMMA. Tissues were collected from stable and aseptically loosened implants and their analysis demonstrated that in all the studied groups of stable implants, the levels of metal ions in the arthral fluid were similar. In turn, aseptic implant loosening coexisted with increased levels of metal ions in the arthral fluid and the synovial membrane, where that increase was disproportionately large in case of titanium alloy implants vs. those of steel and the $\mathrm{Co}-\mathrm{Cr}$ alloy [22]. Similarly Huo, while evaluating a quantitative distribution of metal ions in tissues adjacent to implants and in the articular capsules of patients with aseptic loosening of cemented femoral stem, demonstrated that the levels of $\mathrm{Co}$ and $\mathrm{Cr}$ ions were, on the average, 4 times higher and $\mathrm{Ti}$ ion concentrations were 42 times higher in direct contact with a loosened implant than in the articular capsule [23].

\section{Conclusions}

In soft tissue around a loosened stem, the concentrations of metal ions from implants are much higher in case of uncemented stems than of cemented ones. Metal ions from vitalium femoral heads were found around uncemented stems in similar values to cemented streams. 


\section{Competing interests}

The authors declare that they have no competing interests.

\section{Authors' contributions}

MSi, MSy, KK, PK, MD designed the research, acquired the data and revised it critically for important intellectual content. MSi, , KK analyzed the data and performed statistical analyses. MSi, MSy, KK, MD contributed to interpretation of data. MSi, KK, PK drafted the manuscript. All authors read and approved the final manuscript.

\section{Acknowledgement}

Source(s) of support in the form of grants, equipment, drugs, or all of these - none.

Received: 8 April 2014 Accepted: 29 July 2014

Published: 7 August 2014

\section{References}

1. Sundfeldt M, Carlsson LV, Johansson CB, Thomsen P, Gretzer C: Aseptic loosening, not only a question of wear: a review of different theories. Acta Orthop 2006, 77:177-197.

2. Kaddick C, Catelas I, Pennekamp PH, Wimmer MA: Implant wear and aseptic loosening: an overview. Orthopade 2009, 38:690-697.

3. Świerczyńska-Machura D, Kieć-Świerczyńska M, Kręcisz B, Pałczyński C: Alergy to components of implants. Alergia Astma Immunologia 2004, 9:128-132.

4. Linder L, Lindberg L, Carlsson A, Aseptic loosening of hip prostheses: A histologic and enzyme histochemical study. Clin Orthop Relat Res 1983, 175:93-104.

5. Keegan GM, Learmonth ID, Case CP: Orthopaedic metals and their potential toxicity in the arthroplasty patient: a review of current knowledge and future strategies. J Bone Joint Surg Br 2007, 89:567-573.

6. Hallab NJ, Jacobs JJ: Biologic effects of implant debris. Bull NYU Hosp Jt Dis 2009, 67:182-188.

7. Gruen TA, McNeice GM, Amstutz HC: "Modes of failure" of cemented stem-type femoral components: a radiographic analysis of loosening. Clin Orthop Relat Res 1979, 141:17-27.

8. DeLee JG, Charnley J: Radiological demarcation of cemented sockets in total hip replacement. Clin Orthop Relat Res 1976, 121:20-32.

9. Billi F, Campbell P: Nanotoxicology of metal wear particles in total joint arthroplasty: a review of current concepts. J App/ Biomater Biomech 2010, 8:1-6.

10. Lehmann I, Sack U, Lehmann J: Metal ions affecting the immune system. Met lons Life Sci 2011, 8:157-185.

11. Davda K, Lali FV, Sampson B, Skinner JA, Hart AJ: An analysis of metal ion levels in the joint fluid of symptomatic patients with metal-on-metal hip replacements. J Bone Joint Surg Br 2011, 93:738-745.

12. Hölzer A, Schröder C, Woiczinski M, Sadoghi P, Müller PE, Jansson V: The transport of wear particles in the prosthetic hip joint: a computational fluid dynamics investigation. J Biomech 2012, 45:602-604.

13. Antunes RA, de Oliveira MC: Corrosion processes of physical vapor deposition-coated metallic implants. Crit Rev Biomed Eng 2009, 37:425-460.

14. Jacobs JJ, Silverton C, Hallab NJ, Skipor AK, Patterson L, Black J, Galante JO: Metal release and excretion from cementless titanium alloy total knee replacements. Clin Orthop Relat Res 1999, 358:173-180.

15. Reclaru L, Eschler PY, Lerf R, Blatter A: Electrochemical corrosion and metal ion release from $\mathrm{Co}-\mathrm{Cr}-\mathrm{Mo}$ prosthesis with titanium plasma spray coating. Biomaterials 2005, 26:4747-4756.

16. Cadosch D, Schlett CL, Gautschi OP, Frei HC, Filgueira L: Metal ions: important co-players in aseptic loosening. Z Orthop Unfall 2010, 148:393-397.

17. Zijlstra WP, Bulstra SK, van Raay JJ, van Leeuwen BM, Kuijer R: Cobalt and chromium ions reduce human osteoblast-like cell activity in vitro, reduce the OPG to RANKL ratio, and induce oxidative stress. J Orthop Res 2012, 30:740-747.

18. Jiang H, Liu F, Yang $H$, Li Y: Effects of cobalt nanoparticles on human $T$ cells in vitro. Biol Trace Elem Res 2012, 146:23-29.

19. Andrews RE, Shah KM, Wilkinson JM, Gartland A: Effects of cobalt and chromium ions at clinically equivalent concentrations after metal-on- metal hip replacement on human osteoblasts and osteoclasts: implications for skeletal health. Bone 2011, 49:717-723.

20. Otto M, Kriegsmann J, Gehrke T, Bertz S: Wear particles: key to aseptic prosthetic loosening? Pathologe 2006, 27:447-460.

21. Hirakawa K, Bauer TW, Stulberg BN, Wilde AH, Secic M: Characterization and comparison of wear debris from failed total hip implants of different types. J Bone Joint Surg Am 1996, 78:1235-1243.

22. Brien WW, Salvati EA, Betts F, Bullough P, Wright T, Rimnac C, Buly R, Garvin K: Metal levels in cemented total hip arthroplasty: a comparison of well-fixed and loose implants. Clin Orthop Relat Res 1992, 276:66-74.

23. Huo M, Salvati E, Lieberman J, Betts F, Bansal M: Metallic debris in femoral endosteolysis in failed cemented total hip arthroplasties. Clin Orthop Relat Res 1992, 276:157-159.

doi:10.1186/1471-2474-15-267

Cite this article as: Kmieć et al:: Metal debris concentrations in soft tissues adjacent to loosened femoral stems is higher in uncemented than cemented implants. BMC Musculoskeletal Disorders 2014 15:267.

\section{Submit your next manuscript to BioMed Central and take full advantage of:}

- Convenient online submission

- Thorough peer review

- No space constraints or color figure charges

- Immediate publication on acceptance

- Inclusion in PubMed, CAS, Scopus and Google Scholar

- Research which is freely available for redistribution

Submit your manuscript at www.biomedcentral.com/submit
C BioMed Central 